\title{
A RETÓRICA DO NAUFRÁGIO
}

THE RHETORIC OF THE SHIPWRECK

Cleber Vinicius do Amaral Felipe* cleber.ufu@gmail.com

RESUMO: este artigo apresenta uma maneira verossímil de se ler relatos de naufrágio escritos e publicados ao longo dos séculos XVI-XVIII, tomando-os como exemplares do gênero histórico. Ao invés de lê-los como relato noticioso, realista ou barroco, pretende-se analisar seus códigos linguísticos e operar a partir deles, demonstrando como, naquele período, a história amparava-se na retórica e era concebida como mestra da vida, conforme a duradoura formulação ciceroniana.

PALAVRAS CHAVE: História; Retórica, História magistra vitae.

ABSTRACT: this article presents a verisimilar way to read reports of shipwreck written and published throughout the XVI-XVIII centuries, taking them as exemplars of the historical genre. Rather than reading them as a news story, realistic or baroque, it is intended to analyze their language codes and operate from them, demonstrating how, in that period, the history was based on rhetoric and was conceived as the master of life, according to Cícero's formulation.

KEYWORDS: History; Rhetoric; Magistra vitae history.

A História Trágico-Marítima, de Bernardo Gomes de Brito, contou com o amparo da Academia Real da História Portuguesa, fundada a 08 de dezembro de 1720, por iniciativa do clérigo D. Manoel Caetano de Sousa (1658-1734) e do 4ํㅡㄹ Conde da Ericeira, D. Francisco Xavier de Meneses (1673-1743). Não se pode dizer ao certo se Bernardo Gomes de Brito chegou a fazer parte desta instituição. As poucas informações biográficas sobre ele foram fornecidas por Diogo Barbosa Machado, membro da Academia desde a sua fundação e contemporâneo do coletor. Sabe-se, por exemplo, o nome de seus pais (Domingos Gomes e Mariana de Brito) e o local e a data de seu nascimento (Lisboa, 1688). Além disso, Machado faz alusão à sua "feliz memória", "boa compreensão" e "estudiosa aplicação" (MACHADO, 1741 , p. 532). Nas licenças que acompanham a HTM, existem alguns epítetos que qualificam sua pessoa: no caso, Brito é reconhecido como compilador e cultivador da História que, com cuidado, diligência e curiosidade, coligiu relações de naufrágio úteis e agradáveis.

A História de Brito divide-se em dois tomos, publicados respectivamente em 1735 e 1736. Na editio princeps, o título é apresentado em caixa-alta, com letras capitais: nomeiase, no caso, o gênero (histórico) e a matéria da coletânea (experiências trágico-marítimas). 0

\footnotetext{
* Doutor em História pela Universidade Estadual de Campinas (Unicamp). Professor Adjunto do Instituto de História da Universidade Federal de Uberlândia (UFU).
} 
título é seguido de outras especificações: em que se escrevem cronologicamente os naufrágios que tiveram as naus de Portugal, depois que se pôs em exercício a navegação da Índia. Este texto, que nesta edição se encontra em itálico e com fonte consideravelmente menor, determina a disposição da coletânea (organizada em ordem cronológica) e especifica a matéria (naufrágio de naus portuguesas na Carreira da Índia). Após estes informes, deparamo-nos com o número do tomo, o nome do dedicatário ("Augusta Majestade do Muito Alto e Muito Poderoso Rei D. João V"), o nome do coletor, o selo real, o local em que a obra foi dada à estampa (Lisboa Ocidental), a oficina que a imprimiu (da Congregação do Oratório), a data (em algarismos romanos) e a afirmação de que o exemplar segue com as licenças necessárias para impressão.

No tomo I, com um total de 479 páginas, encontramos a dedicatória ao rei D. João V, as licenças (papal, episcopal e real), um index e seis relações de naufrágio. No tomo II, que soma 538 páginas, constam as licenças, o index e outras seis relações. São, portanto, 12 relações de naufrágio escritas ao longo de 50 anos (1552-1602).

Na dedicatória, Brito utiliza alguns argumentos que conferem um lugar à coletânea, a si próprio e ao rei:

Como V. Majestade, por sua real grandeza, se fez augusto protetor da História, erigindo a sua preclara Academia, parece que permitiu aos afortunados historiadores deste século a glória de recorrer ao seu real asilo, indulto de que agora me valho para pôr aos reais pés de V. Majestade, nestes tomos, estes fragmentos históricos, que já perdem o horror de lastimosos, na fortuna de dedicados, conseguindo eu para aqueles vassalos desta coroa (que agora o são de V. Majestade com melhor estrela) nos seus naufrágios o mais feliz porto, senão para as suas vidas, para as suas memórias. O Céu dilate a vida de V. Majestade para felicidade desta Monarquia (BRITO, 1998, p. 1).

Na posição de historiador, Brito dedica os "fragmentos históricos" que coligiu ao rei D. João V, "protetor da História" e criador da Academia Real de História Portuguesa. Mas qual seria a função do historiador no momento em que a História Trágico-Marítima foi impressa? Evocando uma passagem de Cícero, o clérigo Raphael Bluteau, que também foi membro da referida Academia, afirma que "historiador" é o "escritor de alguma história" (BLUTEAU, 1728, p. 41). A história, para ele, é "narração de coisas memoráveis, que tem acontecido em algum lugar, em certo tempo, e com certas pessoas, ou nações" (BLUTEAU, 1728, p. 39). Estes elementos estão implicados na dedicatória de Brito, quando afirma que 
seu propósito é conseguir para os vassalos da Coroa o mais "feliz porto, senão para as suas vidas, para as suas memórias". Bluteau, ao final, retoma a definição ciceroniana da história: "testemunha do tempo, a luz da verdade, a vida da memória, a mestra da vida, e a mensageira da Antiguidade" (BLUTEAU, 1728, p. 40).

É possível encontrar alguns sentidos para a "história" na primeira proposição da Academia Real da História Portuguesa, acompanhada de um estatuto que define os fundamentos da história que se queria produzir. A intenção, no caso, era constituir duas histórias: uma eclesiástica e outra secular. O proponente, Manoel Caetano de Sousa, comparou a história a um edifício, mencionando os muitos artífices responsáveis por sua construção e a necessidade de uma "planta" na qual se estabelecessem as "regras da arte" convenientes à empreitada. O fruto do trabalho conjunto, no caso, seria um "corpo proporcionado em todas as suas partes". O estilo, no caso, deve ser puro, claro, escrito em língua portuguesa, não como anais, a não ser no que se refere à divisão por matérias, com narração sem interrupção e disposta cronologicamente. A Cronologia e a Geografia foram consideradas os dois "olhos" da história. ${ }^{1}$ Dentre os assuntos que ela trata, não poderiam faltar, claro, as guerras e descobrimentos, temas contemplados pelos "fragmentos históricos" de Brito.

Os esforços dos acadêmicos foram mobilizados não apenas para a escrita da(s) história(s), mas também para a reunião de documentos nos quais os acadêmicos pudessem recolher informes históricos. Essa busca, de acordo com Manoel Telles da Silva, era dificultosa, talvez pela escassez de homens capazes de efetuá-la. A(s) história(s) incluía(m) vários subgêneros, tais como as hagiografias, as genealogias, as crônicas, as notícias, as relações, dentre outros. A "verdade" da história mantinha laços estreitos com a virtude do homem português, ou seja, a produção historiográfica estava atrelada a um tipo característico de serviço prestado à Coroa. Uma das censuras da obra de Telles da Silva, realizada pelo Marquês de Abrantes, propõe um enunciado que chamou nossa atenção:

Se qualquer História é testemunha do tempo, luz da verdade, vida da memória, mestra da vida, e mensageira da antiguidade, que será da História de Portugal? Será testemunha do merecimento, luz da erudição,

\footnotetext{
${ }^{1}$ Ver: Coleção dos documentos, estatutos e memórias da Academia Real da História Portuguesa... História da Historiografia, Ouro Preto, n. 03, 2009, p. 216-235.
} 
vida do entendimento, mestra da heroicidade, mensageira da glória imortal? (SILVA, 1727, s/p).

Após fazer essa pergunta, o censor afirma que a mera transposição de epítetos não seria o suficiente para explicar seu parecer. O autor retoma a tópica ciceroniana da historia magistra vitae e a propõe com novo formato, dessa vez matizando as prioridades da própria Academia. No entanto, este novo formato não refuta ou contraria o antigo: alude-se ao mérito dos portugueses, à erudição e entendimento daqueles que escrevem história, à heroicidade das ações e à fama decorrente delas. Faz-se, portanto, um exercício de particularização da tópica em conformidade com os protocolos da Academia, que continua com o objetivo de propor a exemplaridade da história portuguesa em suas dimensões eclesiástica e secular. O texto em questão trata do que o censor chama de sucessos e ações da "República das Letras", o que justifica muitos dos epítetos utilizados. Aliás, o censor faz um deslocamento muito interessante, para afirmar que a história então narrada não perde em nada perante as histórias antigas, muitas vezes conseguindo superá-la no que se refere não apenas aos exemplos elencados, mas também à escrita empregada.

As informações sobre os autores das relações de naufrágio, no geral, são escassas, mas alguns deles gozam de fama, muitas vezes em razão de outros escritos que lhe foram atribuídos: é o caso de Diogo de Couto, por exemplo, que continuou a escrita das Décadas da Ásia após a morte de João de Barros. João Batista Lavanha, por sua vez, foi cosmógrafomor de Portugal e, além de tratados sobre a arte da navegação, escreveu genealogias de reis. Manuel de Mesquita Perestrelo, que chegou a ser capitão da fortaleza de Maluco por três anos, deixou-nos, em 1576, um roteiro de viagem que orienta no trecho situado entre o Cabo da Boa Esperança e o Cabo das Correntes (MONIZ, 2001, p. 16-21). Sobre outros narradores (caso de Henrique Dias, Manuel Rangel, Gaspar Afonso, Melchior Estácio do Amaral e Manuel Godinho Cardoso) pouco se sabe.

Dos doze relatos, quatro (III, VI, VIII e XI) focalizam a viagem de ida e sete (I, II, IV, V, IX, X, XII) apresentam-nos a torna-viagem. O relato de número VII ocupa-se somente de uma parcela do retorno (Brasil-Portugal). A extensão das narrativas varia: o quarto relato, sendo o menor, soma 33 páginas. O sexto conta com um total de 128 páginas. Dois dos relatos (I, VII) apresentam um prólogo, e apenas um (XII) exibe uma dedicatória. Três deles (VI, X, XI), embora destituídos de prólogo, delimitam bem o exórdio, com informações introdutórias. 
Em termos de invenção, disposição e elocução, os relatos apresentam algumas características em comum: a adoção da narrativa in ordo naturalis, a moderação dos encômios, a opção por uma narrativa clara e verossímil, a valorização do sentido da visão em detrimento da audição, o uso de digressões, exemplos, descrições e amplificações, a recorrência a um gênero humilde ou tênue, a retratação de uma história de caráter providencialista, o domínio de termos náuticos, latinos, astrológicos, a emulação de auctores consagrados pela tradição retórico-poética. ${ }^{2}$ No que se refere à disposição, Giulia Lanciani (1979) sugere o seguinte arranjo: (1) antecedentes-partida, (2) tempestade, (3) naufrágioarribação, (4) peregrinação e (5) retorno-salvamento. A sugestão é pertinente no sentido de orientar a leitura dos relatos, mas nem todos eles reproduzem sistematicamente este ordenamento.

É possível distinguir, em geral, três posturas recorrentes no que se refere aos estudos da História Trágico-Marítima: uma delas concebe a narrativa como sendo um gênero novo, noticioso, marginal, híbrido, escrito com maior "liberdade" em relação aos protocolos retóricos se comparado aos gêneros "canônicos" (LANCIANI, 1979, p. 28-29; MADEIRA, 2005); outra costuma associar os relatos de naufrágio à estética maneirista ou barroca para justificar a presença de uma "retórica da decadência" (CUSTÓDIO, 1992); a última destaca seu teor "disfórico" e apreende os relatos como sendo a contraparte "realista" da fantasiosa "euforia" épica (ZURBACH, 1996; IDEIAS, 1996). Por outras palavras, os relatos de naufrágio são analisados (1) a partir de um suposto "realismo" e de um compromisso em noticiar sem o uso de artifícios retóricos, (2) através de categorias românticas que supõem termos anacrônicos como "estética", "trauma", "decadência", e (3) como gênero "crítico" e, por extensão, antiépico, por supostamente ferir ou reagir à "ideologia" portuguesa tão bem empregada na epopeia lusíada e na historiografia de João de Barros, por exemplo. Parece-nos que estes três procedimentos partem de três equívocos: o primeiro de um conceito tortuoso de retórica e de uma leitura anacrônica do gênero histórico; o segundo busca filiar os exemplares deste gênero a movimentos literários do século XIX, como se fosse possível "ajustar" suas particularidades às teorizações românticas

\footnotetext{
${ }^{2}$ Há referências a poetas (Homero, Virgílio, Ovídio), preceptistas (Aristóteles, Horácio, Cícero, Luciano de Samósata), autoridades do Cristianismo (Jó, Davi, S. Basílio, S. Gregório, S. Paulo, S. Dionísio Areopagita), filósofos (Platão, Aristóteles, Sêneca, Estrabão, Macróbio) e, principalmente, à Sagrada Escritura (sobretudo a fragmentos do Antigo Testamento).
} 
e psicologistas que supõem a naturalidade de categorias como "literatura", "estética", "pessimismo"; o último utiliza pares de conceito como "euforia/disforia", "épico/antiépico", "crítico/acrítico", pressupondo uma dicotomia (uma literatura "oficial" e outra "marginal") que dificilmente acomodaria a diversidade dos gêneros retóricos. Este artigo propõe uma quarta alternativa que possibilita uma leitura verossímil deste subgênero histórico denominado "relação".

Os relatos devem ser lidos a partir das regras discursivas de seu tempo: quando são apreendidos como exteriores à sua própria história (reflexo da realidade, pessimismo, oposição ideológica à empresa descobrimentista, prenúncio do Barroco, originalidade estética e/ou ressentimento psicológico), normalmente deixa-se de lado seu estilo. 0 estilo, no caso, deve ser entendido como linguagem "fortemente regrada por prescrições de produção e de recepção" (HANSEN, 2004, p. 32). Como disse João Adolfo Hansen em seu estudo sobre as sátiras atribuídas a Gregório de Matos, termos como "pessimismo", "ressentimento", "plágio", “imoralidade", "realismo", “oposição nativista crítica”, "libertinagem" e "revolução" podem até apresentar "algum valor metafórico de descrição de um efeito particular de sentido produzido pela recepção", mas não dão conta historicamente do seu funcionamento como prática discursiva de uma época. As tópicas retóricas não devem ser lidas como empiria, pois essa leitura desconsidera as particularidades histórico-retóricas do discurso e valoriza um vivido psicológico improvável.

No que se refere às suas características genéricas, a relação de naufrágio pode ser lida como subgênero das formas historiográficas ou desdobramento do gênero histórico, como é o caso das crônicas, notícias, tratados, panegíricos, anais, vidas, histórias e diários. Todos esses gêneros (ou subgêneros) historiográficos utilizam lugares-comuns epidíticos, tratando-se de uma "prosa imitativo-emuladora" (SINKEVISQUE, 2013, p. 45) e não de transposição de realidades empíricas. A narrativa de naufrágio é trágica, ou seja, determinase o sentido das narrativas como histórias que começam bem e terminam (nem sempre) mal. A experiência trágica, no caso, pressupõe e reafirma a existência de Deus, ou seja, Deus continua atuando providencialmente no tempo mesmo quando os episódios são trágicos. Para melhor compreender as condições de produção dos relatos de naufrágio, é necessário estudar as particularidades do gênero histórico e as tópicas retóricas antigas que continuam a fazer parte de sua narrativa nos séculos XVI-XVIII. 


\section{História e Providência}

Pensemos, agora, nas especificidades da história cristã portuguesa: em primeiro lugar, é preciso levar em consideração que o tempo, neste caso, é considerado criação de Deus (HANSEN, 2006, p. 58). Sendo assim, o conteúdo dos relatos de naufrágio inclui, necessariamente, a presença de Deus, que se repete "em todas as diferenças históricas". Não há punição que não Lhe diga respeito, não há acontecimento no qual Ele não esteja presente. Há, porém, limitação humana, pois o homem não entende com clareza os sentidos da justiça divina. Se todos os momentos históricos são análogos, justamente por implicarem a identidade de Deus, deduz-se que a história pode ensinar maneiras de agir conformadas à vontade da Providência. Neste sentido, a história ensina a reta razão e demonstra como aplica-la ao agir, a partir dos erros ou dos acertos alheios. Em outras palavras, ela ensina prudência.

Em 1552 foi publicada a Primeira Década da Ásia. No prólogo, João de Barros (1778) retrata a diferença entre a "virtude generativa" da Natureza, que é renovável, e os feitos humanos, que dependiam da memória escrita, "Divino artifício" que lega aos pósteros registros das ações e bons exemplos. A "elocução artificial das letras" reúne um conjunto de "caracteres mortos" que contém em si "espírito de vida", afirma o autor. No prólogo da Terceira Década da Ásia, publicada em 1563, Barros emula, inicialmente, o Timeu de Platão, para ressaltar a importância de se conhecer a antiguidade das coisas. Homens que não valorizam as lições de história continuam sendo "moços", com ânimo "sempre mancebo". Mais adiante, o historiador retoma a autoridade de Cícero para censurar aqueles que menosprezam a História e voltam os olhos exclusivamente para o presente, preocupados somente com seus afetos e desejos. Ele mobiliza também os dizeres de Aristóteles, para quem os exemplos do passado não apenas satisfazem o entendimento, mas causam deleite. João de Barros faz uso de uma analogia agudíssima ao apreender a História como campo onde se encontra semeada toda a doutrina Divina, Moral, Racional e Instrumental: quem "pastar o seu fruto" vai convertê-lo em "forças de entendimento" e memória para a condução de uma vida justa e perfeita, aprazível a Deus e aos homens. Barros (1777) não para por aí, pontuando algumas das leis que deveriam ser seguidas pelos historiadores: jamais desviar-se da verdade, não escrever movido pelo ódio, não utilizar argumentos inverossímeis, não desvalorizar a imitação, a eloquência, o decoro. 
De acordo com o licenciado Manuel Severim de Faria, João de Barros, além de ser um súdito exemplar e virtuoso, guardou com muita eficácia todas as leis da história: as partes essenciais (verdade, clareza e juízo) e as partes integrantes. Além disso, o licenciado encontra nos escritos deste historiador o bom uso dos três gêneros retóricos (demonstrativo, deliberativo e judiciário), uma escrita clara, com uso prudente da descrição, com justa disposição e exemplos dignos de registro. Decerto Severim de Faria compôs uma Vida, gênero retórico afinado ao demonstrativo pela vertente encomiástica. Nestes termos, o louvor é menos um retrato subjetivo e autônomo e mais um retrato objetivo, que inventa tipos, personae dignas de imitação justamente por atender às prerrogativas do poder constituído e integrar a memória do auditório, que reconhece no elogio um modus operandi adequado às circunstâncias de seu presente.

No prólogo de sua História do descobrimento \& conquista da índia pelos Portugueses (1554), Fernão Lopez de Castanheda menciona a utilidade da história, que ensina o que devemos fazer e de que devemos fugir. No entanto, ele afirma que as lições de história são muito mais úteis aos príncipes do que aos homens privados, pois o erro de um governante atinge todos que ele governa, ao passo que o erro de um privado atinge somente a ele. Por isso, o príncipe deve retirar da história a melhor maneira de aperfeiçoarse, pois ela instrui através da experiência e dos exemplos. Castanheda utiliza, ainda, da amplificação, para retratar a superioridade dos feitos portugueses em relação aos feitos passados. Amplifica também a importância de se ver os lugares sobre os quais discorre, para evitar equívocos muitas vezes repetidos pelos historiadores que o precederam. Este historiador consultou cartas, sumários e colheu testemunhos de pessoas "dignas de fé". No prólogo do livro três, salienta também o fato de ele ser homem "experimentado", que viu tormentas, batalhas no mar, navios naufragando, tudo para amplificar a autoridade do seu relato como fruto da visão ou da experiência.

Nos relatos de naufrágio existem duas grandes fórmulas em se tratando da exemplaridade da história: em uma, busca-se ensinar prudência através do relato das viagens e dos erros ou acertos dos homens de outrora. Na outra, pretende-se preservar a memória da intervenção providencial, única realmente capacitada a livrar os nautas dos grandes males ocorridos no decorrer da viagem. 
Na carta dedicatória do relato de naufrágio da nau Conceição (1627), por exemplo, João Carvalho Mascarenhas declara a serventia de sua narrativa, que é fundada "sobre uma matéria de pouca estima e baixo sujeito, por serem sucessos acontecidos entre escravos e cativos", o que não deixa de ter algum espírito e curiosidade, nem deixa de "ser exemplar em história" (PERES, 1937, p. 25). Quanto aos trabalhos mencionados no relato, diz ele, "não perde nada sabê-los quem não os experimentou" (PERES, 1937, p. 25). A utilidade da matéria tratada fica ainda mais evidente no trecho seguinte: "Não se isentando ninguém por mais próspero que seja, de cuidar que the pode acontecer o que tem acontecido a tantos, e o que tem notícia de coisas semelhantes já sabe se há-de haver nelas" (PERES, 1937, p. 25).

Padre Júlio Francisco, responsável pela licença do Ordinário que se encontra no primeiro tomo da coletânea, afirma que Bernardo Gomes de Brito trata dos "lastimosos" e "infelices" sucessos das naus da Carreira, reunidas em um livro cuja lição, suave e agradável, não desagrada em nada os bons costumes da Santa Fé. Ele é utilíssimo "para que os que houverem de navegar, desenganados dos muitos e gravíssimos perigos de vida a que se expõem, concebam um santo temor da morte", e para "os que ficarem em terra compadecendo-se dos navegantes os ajudem com fervorosas orações a escapar de tamanhos perigos: e todos nas calamidades de sucessos tão lamentáveis aprendam a miséria e inconstância deste mundo" (BRITO, 1735, s/p). A licença em questão data de julho de 1729. Na licença do Paço, de agosto de 1729, Frei Lucas de Santa Catharina é brevíssimo ao mencionar a dignidade do trabalho do compilador, "útil aos cultivadores da Historia". Frei Manoel de Sá, na licença do Santo Ofício, afirma tratar-se de um "teatro da História", no qual é encenado um papel "verdadeiramente trágico" e exemplar.

Padre José Troyano, na licença do Santo Ofício do segundo tomo da coletânea, insiste na necessidade de se relatar as ocorrências do naufrágio como paga pela salvação providencial, citando a autoridade do Eclesiástico: "Qui navigant mare, enarrent pericula". Este é um fragmento da passagem bíblica que diz o seguinte: "Os que navegam sobre o mar contam os seus perigos; ouvindo-os, ficaremos arrebatados de admiração" (Ec 43: 26). Só experimentando a braveza do mar e a força da tormenta para "representar vivamente" uma tempestade desfeita. Desta vez, o padre cita Virgílio para estabelecer uma analogia entre a prática antiga de pendurar no Zambujeiro (espécie de oliveira) os despojos do naufrágio e o livro de Brito, que dá a conhecer os naufrágios portugueses. Como o fragmento encontra-se 
em latim, segue a tradução para o português de José Victorino Barreto Feio e de José Maria da Costa e Silva:

\author{
Sagrado, acaso, a Fauno um zambujeiro \\ De amargas folhas nesse campo havia, \\ Lenho outrora dos nautas venerado, \\ Que ao naufrágio escapando, vinham nele \\ Dons pendurar ao Nume de Laurente \\ E as devotadas vestes (VIRGílIO, 2004, p. 404).
}

Nota-se, portanto, que a serventia do livro é múltipla: é obra que comove e incentiva o "agradecimento a Deus Senhor Nosso" pelas misericórdias recebidas e também é útil "aos que navegam às partes da Índia, e continuamente cursam aquela Carreira, para que no perigo alheio aprendam a evitar o próprio" (BRITO, 1736, s/p). A censura do Frei José da Assumpção, Qualificador do Santo Ofício, diz que o livro deve ser apreendido como

espelho em que cada um dos que neste proceloso mar deste mundo vivem,
todos os dias se contemplem: pois nada menos (proporcionadamente) em a
terra se encontra, do que em mar acontece: certo para a terra, e mar he
este livro útil, e proveitoso, porque dos infortúnios, que em hum e outro
elemento se experimentam, e das misericórdias de Deus, que tanto em
uma como em outra parte nos assistem, faz a expressam que basta para
todos crerem estas já mais não hão de faltar a quem souber animosamente
depreca-las: lograram-na os invictos Varões dos quais esta presente história
nos faz especial menção (BRITO, 1736, $\mathrm{s} / \mathrm{p}$ ). O censor menciona a grandiosidade da história narrada e dos nautas que a protagonizaram, pois "as adversidades não puderam eximi-los do amor que à virtude tinham". Ele cita Lucano, que diz "Crevit in adversis virtus" (Sua coragem cresceu com a adversidade) e um provérbio latino, "Felix, quem faciunt aliena pericula cautum" (Feliz daquele que aprende com os erros alheios), para conferir autoridade à seguinte assertiva: "são ditosos para o mundo aqueles a quem os perigos alheios fazem acautelados para em semelhantes não caírem". Outra utilidade do livro é a possibilidade de "aprender nele o como se alcança de Deus a sua piedade, temendo a Divina justiça, avisados de outros, antes que de si mesmos se valham". Frei José de Assumpção menciona o que disse Valerius Maximus: "Lento gradu ad vindictam sui Divina procedit ira, tarditatemque suplicii gravitate compensat" (A ira divina avança em passo lento para a vingança Sua, mas compensa com a gravidade o tardio do suplício), e Provérbios, "Quem diligit Dominus corripit", fragmento do versículo "Porque o Senhor repreende aquele a quem ama, assim como o pai ao filho a quem quer bem" (Pro 3: 12). Frei Xavier de Santa Tereza, responsável pela licença do Paço, 
emula o relato de naufrágio narrado pelo cosmógrafo João Baptista Lavanha ao dizer que o livro de Brito é o "melhor Roteiro a todos os navegantes dos mares da Índia", no qual não se pode achar nada que se oponha ao espírito das "prudentes Reais Leis" (BRITO, 1736, s/p).

No exórdio no relato de naufrágio da nau Santo Alberto, o narrador menciona como este texto pode orientar a partir da prudência, pois o naufrágio

ensina como se devem haver os navegantes em outro que thes pode acontecer, de que remédios proveitosos usarão nele e quais são os aparentes e danosos de que devem fugir, que prevenções se farão para ser menor a perda no mar e mais segura a peregrinação por terra, como com menos perigo desembarcarão nela. $E$ a causa da perdição desta nau (que é o quase de todas as que se perdem), a relação do caminho mostra qual devem seguir e deixar, que apercebimentos farão para a sua grandeza e dificuldade, como tratarão e comunicarão com os cafres, com que meios farão com eles o necessário comércio, e sua bárbara natureza e costumes (BRITO, 1998, p. 375).

Na sequência, ele complementa:

E para que de cousas tão importantes e novas se tenha o necessário conhecimento, escrevo este breve tratado, resumindo nele um largo cartapácio que desta viagem fez o piloto da dita nau, o qual emendei e verifiquei com a informação que depois me deu Nuno Velho Pereira, capitão-mor que foi dos portugueses nesta jornada (BRITO, 1998, p. 375).

O "cartapácio" é um livro de mão, em que se escrevem várias matérias. Em outras palavras, o narrador entra em contato com as anotações do piloto, que confere e emenda com a ajuda de Nuno Velho Pereira, capitão de Sofala (Moçambique), que esteve nesta jornada. A posição do narrador, na situação de "cosmógrafo-mor", justifica a introdução e os apontamentos sobre a utilidade dos relatos de naufrágio.

Há um sentido providencial que orienta a história. Basta retomar a licença do padre José de Assunção, qualificador do Santo Ofício, quando diz que se aprende, com estas relações, "como se alcança de Deus a sua piedade, temendo a Divina justiça, avisados de outros, antes que de si mesmos se valham". Ou seja, aprende-se a navegar, mas também a temer a justiça divina e os meios de se alcançar sua piedade. Na sequência, ele diz que os castigos de Deus, "ensaios da sua ira", são também "prendas do seu amor", e é nesse momento que a ideia de "pessimismo" ou de "decadência" torna-se ineficaz. Não que a opinião de um censor venha a dirigir a leitura de todos os relatos, mas essa é uma tópica presente em Tomás de Aquino, que as retira da Bíblia para representar a justiça insondável de Deus, que nem sempre é inteligível para os homens. Deus testa o homem, como fica claro 
em algumas passagens do livro sagrado, e pune com a intenção de fazê-los aliviar o peso dos pecados e, assim, alcançar a salvação. É por isso mesmo que o leitor atual estranha e considera inverossímil a atitude de Jorge de Albuquerque, que se mantêm firme na fé mesmo frente aos mais terríveis infortúnios. A leitura do livro de Jó, por exemplo, ajuda-nos a compreender como as obras divinas, mesmo quando inconsistentes frente ao que espera o homem, têm um sentido justo, salvífico.

No prefácio do relato de naufrágio da nau Conceição (1627), João Carvalho Mascarenhas evidencia que pretende "contar verdades". Para tanto, afirma ter sido "testemunha de vista" e abre mão de "adorno de palavras" e de "linguagem floreada", que causam mais confusão que gosto. Além disso, afirma que sua história atende aos critérios da clareza e brevidade, atentando para as recomendações do decoro (PERES, 1937, p. 25). Na sequência, ele frisa mais uma vez o gosto decorrente da narrativa: "e posto que o contentamento de contar trabalhos passados me pode ficar por prêmio, o ser bem aceita o terei por tão grande, quanto é o gosto com que a ofereço" (PERES, 1937, p. 28). O narrador se aproxima da história pragmática de Tucídides, Políbio e Gandavo, na medida em que dispensa o adorno e a linguagem floreada e utiliza as tópicas da clareza e brevidade. João Carvalho Mascarenhas aproxima-se dos historiadores gregos da Antiguidade mais uma vez quando afirma ter sido "testemunha de vista" e quando informa sua posição política e militar, já que serviu/militou na Índia em atenção aos ditames da Coroa. A superioridade da visão é central como forma de assegurar a verdade, como ocorre em Tucídides, por exemplo, que prioriza o sentido da visão em detrimento da audição por julgar a memória muito frágil.

O exórdio do relato de naufrágio da nau São Francisco levanta elementos que, igualmente, reforçam a imprescindibilidade da utilidade e do deleite (BRITO, 1998, p. 427). Ao fazer uso da tópica da amizade, indicando que o relato foi escrito a pedido de outro a quem devia obediência, o padre Gaspar Afonso efetua a captatio benevolentiae, ou seja, seu relato é produto mais da obrigação para com um superior do que necessariamente fruto da vontade pessoal. Após mencionar o gosto que a narrativa de infortúnios causava em seus pares, o narrador amplifica sua "larga e trabalhosa peregrinação" ao afirmar que conheceu mais lugares do que Ulisses em sua empresa épica. Se lembrarmos da opinião de Políbio segundo a qual o herói homérico representa convenientemente a função do historiador 
ideal justamente por ter conhecido muitos lugares e passado por muitos trabalhos, é possível entender o teor valorativo dessa analogia. Na sequência, o narrador adverte sobre a brevidade do seu escrito, lugar comum que, como veremos, se faz presente na grande maioria dos relatos de naufrágio. Para justificar seu empreendimento, ele destaca que escreveu com "dobrado interesse". Quando fala do seu interesse, ele invoca dois auctores: Sêneca, que diz ser coisa natural folgar cada um com o fim de seus males (Gandavo também utiliza o termo folgar em sua dedicatória), e Macróbio, ao referir-se à transmissão, por parte de pessoas que experimentaram grandes perigos e deles escaparam, de uma memória por meio da palavra transmitida como pintura, de forma a "pôr diante dos olhos alheios" o ocorrido. Nota-se, aqui, que a vivacidade do relato é tida como critério de verossimilhança, como meio de transmissão de uma "pintura" por intermédio de palavras. Trata-se do ut pictura poesis horaciano, que assegura a equivalência entre os ofícios de poetas e pintores.

Quando o padre Gaspar Afonso fala da outra parte interessada, isto é, do leitor, ele requisita, implicitamente, a autoridade de Sêneca ao referir-se a um episódio do seu Hércules furioso envolvendo Anfitrião e Teseu:

Anfitrião. Deus, que tem o poder, favoreça o meu desejo e assista minhas fraquezas. Ó magnânimo companheiro de meu grande filho, revela o elenco de suas virtudes: quão longo é o caminho que conduz aos tristes manes; como suportou duros grilhões o cão do Tártaro.

Teseu. Tu me obrigas a recordar ações horrendas mesmo para uma mente tranquila. A custo, ainda, há certeza da aura vital; turva-se a luz de meus olhos e minha vista enfraquecida apenas suporta o desabituado dia.

Anfitrião. Vence, Teseu, por completo, tudo o que de pavor resta no fundo de teu peito e não prives do melhor fruto de teus trabalhos: o que foi duro de suportar é doce de se lembrar. Conta as horrendas desventuras (MARCHIORI, 2008, p. 75-76).

O leitor do relato, no papel de Anfitrião, estaria pedindo ao narrador, que ocupa posição análoga à de Teseu, "que o não privasse do doce fruto" de seus trabalhos, "os quais quanto mais duros foram de sofrer tanto mais docemente lembram" (BRITO, 1998, p. 427). O sofrimento, portanto, não impede a obtenção de deleite, muito pelo contrário: ele o amplifica.

Também é esclarecedor o prefácio do relato de naufrágio da nau Santo Antônio, capitaneada por Jorge de Albuquerque Coelho, em que autor recorre à tópica tucidideana do ktema es aiei (aquisição para sempre) em seu “breve Sumário” (BRITO, 1998, p. 263-264). 
Alude-se, no caso, a Hipócrates, mas para mencionar um procedimento que também é o de Tucídides, isto é, o de insistir que o escrito deve ter serventia, utilidade. Convém mencionar, mais uma vez, o relato de Tucídides sobre a peste de Atenas, que apresenta uma função similar à das tábuas de Hipócrates citadas por Estrabão.

O narrador faz referência à brevidade do relato e simula modéstia ao dizer que depende da benignidade do leitor. Em seguida, ele diz que seu escrito tem as mesmas razões de ser que as tábuas de Hipócrates: primeiro, a função de notificar e, portanto, de ser útil; a segunda, de legar aos pósteros remédio, possível com base em "lágrimas, contrição e arrependimento". O uso da tópica do remédio, muito comum nas letras portuguesas dos séculos XVI, XVII e XVIII, se articula, neste caso, à metáfora aristotélico-escolástica do corpo político. No caso, a saúde de Portugal depende do bem comum, da concórdia entre seus membros. Logo, a história propicia remédio para combater as doenças do reino, sejam elas físicas, morais, políticas.

Na sequência, o narrador vale-se de uma informação correlata àquela do relato de naufrágio da nau São Francisco, possivelmente inspirada em Sêneca: "ainda que nossa natureza é sujeita aos trabalhos, todavia não agasalha bem a lembrança deles". A ideia é reforçada na sequência: "e quem diz que a lembrança dos trabalhos passados dá gosto, não se viu nunca nestes nem em outros semelhantes", pois "o gosto que se recebe da memória deles nasce do descanso em que se vê quem os passou e não do lembrar-se de ver tão particularmente a morte no olho, como dizem". Lisa Voigt nota que este prefácio apresenta algumas diferenças em relação ao texto original. Na primeira edição, afirma-se: "assim como a memoria dos dias alegres, \& felices, conforme a openião de alguns Philosophos, causa tristeza, \& dór em outros estados diferentes, assim a memoria dos males, \& dos trabalhos, fora delles, causa deleytação, \& contentamento" (VOIGT, 2008, p. 208). É possível que, dentre os filósofos que menciona, encontrem-se Aristóteles e Cícero.

Faz-se referência, por fim, a Virgílio, grande poeta que "pôs muito receio de contar os trabalhos passados, dizendo que lhe fugia o entendimento da lembrança deles". Assim, o narrador alega que seu escrito veio à luz por duas razões: porque, de outra forma, teria sido ingratidão não contar as grandes mercês recebidas de Deus, e por não haver outra pessoa disposta a fazê-lo (argumento similar é utilizado por Gandavo em sua História). Com modéstia afetada, o narrador afirma que contou com o apoio de Jorge de Albuquerque, 
principal da nau, que recordou coisas que o escritor havia se esquecido, o que não impediu a brevidade da narrativa. Como é de praxe, a modéstia é requerida no desfecho do prefácio: "Pelo que peço não olhem às palavras, que são as que são, mas o intento, que é ser o Senhor louvado para sempre".

No relato de naufrágio da nau São Paulo, Henrique Dias, com modéstia, afirma optar pela escrita concisa e verdadeira. A grandiosidade da verdade, no caso, deveria compensar as faltas de Henrique Dias, no que se refere ao seu "humilde" engenho. Além disso, ele afirma que o agrado decorrente das narrativas breves é preferível ao fastio causado pela prolixidade. Assim, Dias refere-se àquilo que não fará parte de sua narrativa por não ser matéria de seu entendimento, como dados técnicos relativos ao caminho trilhado pela nau, que é assunto dos "homens do mar". Para ilustrar seu posicionamento, ele retoma, provavelmente via Plínio, o Velho, e sua História Natural, a anedota de Apeles e o sapateiro. Em suma, um sapateiro sugeriu ao pintor Apeles uma mudança na representação da sandália, orientação que o pintor atendeu prontamente. No entanto, o sapateiro, entusiasmado, resolveu fazer uma crítica ao rosto do retratado, ao que Apeles teria respondido: "Ne supra crepidam sutor judicaret", ou seja, um sapateiro não deve julgar algo para além de seu ofício. Embora a frase presente no relato seja outra, "que o sapateiro com o sapato e o barqueiro com a barca", o sentido é o mesmo: cada um deve se ocupar com aquilo que the diz respeito. No final, o narrador refere-se à sua "história" e pede pela benevolência do leitor "mais entendido", isto é, discreto, para que, na ocasião de possíveis erros, estes devem ser emendados com "bom ânimo e vontade, deitando tudo à melhor parte" (BRITO, 1998, p. 195-196).

Na censura do Ordinário, de Júlio Francisco, encontra-se presente a tópica horaciana que associa utilidade e deleite, no momento em que ele diz que a "lição" que propõe a História Trágico-Marítima é "suave" e "agradável", o que fez com que a lesse num curto espaço de tempo. Além disso, o censor adverte que a narrativa é útil em diferentes aspectos: para os que forem navegar, pois propõe o desengano em relação aos perigos que existem no mar, para ensinar a importância do "temos da morte", para orientar aqueles que ficam em terra e que devem rezar pelos seus, e para evidenciar a "miséria e inconstância deste mundo". A tópica da inconstância do mundo, como se pode ver, ao propor a 
contingência e suas dinâmicas, faz ver que a "máquina do mundo" não é inteiramente previsível.

No prólogo da segunda edição da relação de naufrágio da nau Santo Antônio, publicada em 1601, Antonio Ribeiro refere um conjunto de tópicas que já mencionamos em outras ocasiões: a da obrigação para com o dedicatário, o deleite proveniente de matéria trágica após sua ocorrência, a exemplaridade das ações e, claro, a modéstia afetada, que exige benevolência por parte do leitor discreto, em razão da precariedade do escrito que lhe é dado a ler. Além disso, Antonio Ribeiro traça um breve retrato do dedicatário Jorge de Albuquerque, detentor de engenho, urbanidade e liberalidade. Estes atributos foram mencionados após a descrição de situações das quais participou o herói, como a luta contra o índio em Pernambuco e a guerra contra o gentio no norte de África, na qual Jorge de Albuquerque supostamente cedeu seu cavalo ao rei para salvar-lhe a vida. Fica evidente, portanto, a tópica das letras e armas e o tom encomiástico deste discurso preambular (PILOTO, 1601, s/p). Vale lembrar que, após estes dizeres, há um soneto em que o herói é comparado a antigos heróis, superando a todos.

Amaral segue de muito perto os passos de Antonio Ribeiro, como se pode ver na dedicatória a d. Teodósio e no capítulo introdutório (AMARAL, 1604, s/p). De todas as relações de naufrágio, esta talvez seja a que melhor define o gênero: assinala o valor do testemunho, reforça a importância da experiência, indica que sua matéria supera a dos filósofos, matemáticos e cosmógrafos, que muitas vezes escreviam sobre o assunto sem têlos vivenciado, reformula a tópica do deleite decorrente das ações trágicas, dizendo que o afeto resultante delas é a compaixão, amplifica a importância das relações que colige em detrimento de todas as outras, vale-se da modéstia afetada, menciona o teor instrutivo decorrente do seu tratado e chama a atenção do leitor para a inconstância (ou desconcerto) do mundo, que exige prudência e, portanto, advertências provenientes da história.

Aqueles que dizem que o mar das tragédias marítimas figura metonimicamente as penas do inferno se esquecem de que as histórias trágico-marítimas não são meras transposições de fatos, como fica evidente em seus discursos preambulares. Os autores que afirmam que o relato de naufrágio representa o lado mais "realista" da empresa ultramarina se esquecem de que a "verdade" histórica, neste caso, é escrita a partir de um elenco de lugares comuns que buscam assegurar este efeito de verdade, que é modelado 
retoricamente e, portanto, não conhece o realismo e subjetivismo românticos que surgem com a(s) literatura(s) do século XIX. Aqueles que tomam o naufrágio como metonímia de uma decadência portuguesa não se recordam de que incidentes marítimos abundam em histórias e epopeias desde a Antiguidade, e que a fragilidade humana foi representada já nas mitologias greco-romanas, não sendo atributo particular do que reconhecem como sendo o "Barroco". Por fim, aquele que lê o relato de naufrágio como sendo o reverso da dimensão positiva da epopeia se esquece de que epopeia não é apenas luz, e que história não é somente penumbra. Para letrados católicos que creram em Deus e, portanto, na orientação providencialista da história, seria impossível apreender um mundo no qual só existissem labores e penúrias. Por isso mesmo, é difícil falar de "pessimismo" ou de "decadência", pois há uma retórica prudencial que une os mais diversos gêneros em um mesmo projeto salvífico.

\section{REFERÊNCIAS BIBLIOGRÁFICAS}

AMARAL, Melchior Estácio do. Tratado de batalhas. Lisboa: Oficina de António Álvarez, 1604.

ANDRADE, Luiz Cristiano. Os preceitos da memória: Manuel Severim de Faria, inventor de autoridades lusas. História e Perspectivas, Uberlândia, EDUFU, n. 34, 2006.

ARISTÓTELES. Retórica. Tradução, textos adicionais e notas de Edson Bini. São Paulo: EDIPRO, 2011.

BARROS, João de. Da Asia: Dos feitos, que os Portuguezes fizeram na conquista, e descubrimento das terras, e mares do Oriente - Década primeira (parte primeira). Lisboa: Regia Officina Typografica, 1778.

BARROS, João de. Da Asia: Dos feitos, que os Portuguezes fizeram na conquista, e descubrimento das terras, e mares do Oriente - Década terceira (parte primeira). Lisboa: Regia Officina Typografica, 1777.

BLUTEAU, Raphael. Vocabulario portuguez \& latino: aulico, anatomico, architectonico... Coimbra: Collegio das Artes da Companhia de Jesu, 1712-1728.

BRITO, Bernardo Gomes de. História Trágico-Marítima. Em que fe efcrevem chronologicamente os Naufragios que tiveraõ as Naos de Portugal, depois que fe poz em exercicio a Navegaçaõ da India. Tomo primeiro. Lisboa Ocidental: Officina da Congregação do Oratório, 1735.

BRITO, Bernardo Gomes de. História Trágico-Marítima. Em que fe efcrevem chronologicamente os Naufragios que tiveraõ as Naos de Portugal, depois que fe poz em exercicio a Navegaçaõ da India. Tomo segundo. Lisboa Ocidental: Officina da Congregação do Oratório, 1736.

BRITO, Bernardo Gomes de. História Trágico-Marítima. Rio de Janeiro: Lacerda Editores, 1998.

CASTANHEDA, Fernão Lopez de. História do descobrimento \& conquista da Índia pelos Portugueses. Coimbra, 1551-1561, 8 vol. Disponível em: http://purl.pt/15294. Acesso em: mar. 2013. 
Coleção dos documentos, estatutos e memórias da Academia Real da História Portuguesa... História da Historiografia, Ouro Preto, n. 03, 2009, p. 216-235.

CUSTÓDIO, Pedro Balaus. A História Trágico-Marítima: do herói ao anti-herói (Dissertação de mestrado). Coimbra: Faculdade de Letras da Universidade de Coimbra, 1992.

HANSEN, João Adolfo. A sátira e o engenho: Gregório de Matos e a Bahia do século XVII, São Paulo: Ateliê Editorial, Campinas: Editora da Unicamp, 2004.

HANSEN, João Adolfo. Barroco, Neobarroco e Outras Ruínas. Floema Especial (UESB), ano II, n. 2, 2006.

IDEIAS, José António Costa. A Relação de viagem e naufrágio da nau "São Paulo", de Henrique Dias. Consagração martirológica e libelo acusatório. In: SEIXO, Maria Alzira; CARVALHO, Alberto (orgs.). A História Trágico-Marítima: análises e perspectivas. Lisboa: Edições Cosmos, 1996.

LANCIANI, G. Os relatos de naufrágios na literatura portuguesa dos séculos XVI e XVII. Portugal: Instituto de Cultura Portuguesa, 1979.

MACHADO, Diogo Barbosa. Bibliotheca Lusitana, Historica, Critica, e Cronologica... Tomo I. Lisboa: Oficina de Antonio Isidoro da Fonseca, 1741.

MADEIRA, A. Livro dos naufrágios: ensaio sobre a história trágico-marítima. Brasília: Editora Universidade de Brasília, 2005.

MARCHIORI, Luciano Antonio B. S. Hércules furioso de Sêneca: estudo introdutório, tradução e notas (Dissertação de mestrado). São Paulo: Universidade de São Paulo (USP), 2008.

MONIZ, António Manuel de Andrade. A História Trágico-Marítima: Identidade e Condição Humana. Lisboa: Edições Colibri, 2001.

PERES, Damião (org.). Viagens e naufrágios célebres dos séculos XVI, XVII e XVIII, vol. 1. Porto: Tipografia e Encadernação Alberto de Oliveira, 1937.

PILOTO, Afonso Luís. Naufrágio que passou Jorge de Albuquerque Coelho. Lisboa: Oficina de António Álvarez, 1601.

POLíBIO. História. Seleção, tradução, introdução e notas de Mário da Gama Kury. Brasília: Editora Universidade de Brasília, 1996.

SILVA, Manoel Telles da. História da Academia Real da História Portugueza. Lisboa: Officina de Joseph Antonio Sylva, 1727.

SINKEVISQUE, Eduardo. Usos da ecfrase no gênero histórico seiscentista. In: História da Historiografia, Ouro Preto, n. 12, 2013, pp. 45-62.

VIRGílIO. Eneida de Virgílio. Tradução de José Victorino Barreto Feio e José Maria da Costa e Silva. São Paulo: Martins Fontes, 2004, livro décimo segundo.

VOIGT, Lisa. Naufrágio, cativeiro, e relações ibéricas: a História trágico-marítima num contexto comparativo. Varia Historia, Belo Horizonte, vol. 24, n. 39, 2008. 
ZURBACH, Christine. História e ficção nos relatos de naufrágio. O caso da "Relação da muy notavel perda do Galeão Grande São João". In: SEIXO, Maria Alzira; CARVALHO, Alberto (orgs.). A História Trágico-Marítima - Análises e perspectivas. Lisboa: Edições Cosmos, 1996. 